\title{
Researching of Pasta Quality With The Usage of Legumes Flour and Ozonated Water
}

\author{
G.K. Iskakova, T.K. Kulazhanov, B.A Iztaev, \\ B.Zh. Muldabekova and A. Zhilkhaidarov \\ Almaty Technological University, Kazakhstan, 020000, Almaty. \\ DOI: http://dx.doi.org/10.13005/bbra/1878
}

(Received: 19 September 2015; accepted: 20 November 2015)

\begin{abstract}
On the basis of the obtained experimental data is established that use of the ozonated water at preparation of dough promotes the improvement of a gluten quality, properties of dough and quality of pasta from mix of wheat and pea flour. From the viewpoint of improving the quality of pasta optimal dosage pea flour is $15 \%$, the ozone concentration $2 \mathrm{mg} / \mathrm{l}$. The use of legumes flour suitable for enrichment of pasta with valuable food components- proteins, essential amino acids, vitamins and minerals.
\end{abstract}

Key words: pasta, the pea flour, the ozonated water, technological properties.

The idea of improving the health of the population by creating the conditions for a balanced diet is now officially recognized in Kazakhstan. The State Program of Health Development 2011 - 2015 years the concrete tasks in the field of healthy nutrition were delivered, aimed at social mobilization of society to solve this problem and formation of the country's population skills of healthy nutrition. It, certainly, has to affect to improvement of the main medicodemographic indicators, decrease in prevalence of socially significant forms of pathology, formation of competitive productive forces (Medvedev, 2005).

One of the main directions of the state policy in the healthy nutrition area of the population of Kazakhstan is the creation of qualitatively new production technologies of food products with directional change in chemical composition, including product functionality, as well as the elimination of the existing deficiency of protein, vitamins, macro minerals, and other

\footnotetext{
* To whom all correspondence should be addressed. E-mail: zhanat_2006@mail.ru
}

essential substances. It's necessary to prevent the protein, vitamin and mineral deficiencies in the general population by focusing on the everyday products and mass consumption, which the pasta is (Iskakova et al., 2011).

To improve the nutritional and biological value of pasta the great importance to the use of legumes attaches, which includes peas, beans, lupines, broad beans, vetch, rank, soybeans, chickpeas, lentils, and others. Legumes are an important and integral part of a specific grain complex as they solve the problem of providing the population with valuable, high-quality food (Abecassis, 2001). Seeds of legumes are an important source of high-value protein food. Protein of bean cultures is rich with irreplaceable amino acids, especially the lysine which contents is 2-2,5 times higher, than in protein of cereal cultures. Bean cultures the unusual oil, including all components close to lipids of fishes, magnificent ensemble of absolutely unique biologically active components, such as lecithin, is well-cared, vitamins of groups B, E, D, macro and microcells and some other substances (Kulazhanov et al., 2008).

In recent years, more and more widely 
used in the food industry are ozone and ozone technology, having a number of advantages over special additives and technologies (D'Egidio et al., 1990). Almaty Technological University scientists conducted research in use of ozonated water and ionoozonated in the production of bakery products, pasta, and flour confectionery products made from wheat flour and flour from wheat, cereals, oilseeds and legumes that improve quality, safety and environmental cleanliness of finished products. Application of agents of ion ozone technology has many useful properties (antibacterial, redox, etc.) in the production of food it is the latest trend of and represents a promising trend in the production of food (Kosovan \& Polandova, 2004).

Due with the above research aimed at improving the nutritional and biological value of pasta, to improve their organoleptic and physicochemical parameters, broadening the range based on the use of flour from legumes and ozonated water are relevant (Abdraimov, 2011).

\section{METHOD}

For experimental studies used wheat flour, pea flour, ozonated water and determined the properties of gluten dough and the quality of the pasta.

Research Methods of quantity of crude gluten, hydration ability, IDK indication, elasticity and tensile properties of a gluten are stated in the corresponding management (Panzhin, 2006)

The rheological properties of the dough were determined on alveograph of Chopin and Brabender's farinograph (Del Nobile, 2000).

The following quality of flour is evaluated on alveograph it's: elasticity test, the ratio of elasticity to tensile compressive deformation test.

To assess the quality of flour on farinogr aph was determined the following indicators - water absorption capacity, the formation of the test, stability test, the degree of dilution, valor metric assessment.

Organoleptic and physico-chemical quality of pasta was determined according to the manual (Maemerov et al, 2011).

To determine the appearance (color, surface condition and shape) pasta sample was placed on a smooth surface, gently stirred and treated (Cacak-Pietrzak et al,1997).

Moisture was determined by drying of thoroughly crushed pasta in an oven of mark ENR - 3M at 1300C for 40 minutes and expressed as a percentage (Vasilenko \& Komarov, 1987)

The acidity of the pasta was determined by water shaker and expressed in degrees.

Cooking properties of pasta are characterized by the following parameters: duration of cooking until readiness, the amount of absorbed water, the losses of dry matters, strength of welded products, the degree of cohesiveness of welded products (Feillet, 2000).

\section{RESULTS}

Insoluble proteins play significant role in the technological process of pasta production- gliadin and glutenin, which form a peculiar complex of proteins called gluten during a kneading dough.

In this regard, we studied the effect of pea flour in dosages of $2.5 ; 5 ; 7.5 ; 10 ; 12.5 ; 15$; $17.5 ; 20.0 \%$ on the properties of gluten, as a main structural elements of the wheat flour.

The results of researches of the effect of making pea flour on the properties of gluten (the amount of wet gluten, hydration ability, reading DCO, elasticity, elongation) are shown in Table 1.

The obtained data allows to note that with a dosages increasing of a pea flour properties of a gluten, that is expressed in reduction of mass of a crude gluten and deterioration of its quality. So, with increasing of the dosages of a pea flour from 2,5 to $20,0 \%$ the maintenance of a crude gluten decreases by $0,5-4,6 \%$ in comparison with a control sample.

In the increasing process of the content of pea flour the quality of Gluten deteriorate. However, with the introduction of 2.5 and $5.0 \%$ of pea flour to wheat flour weight readings of DCO were respectively, 72 and 74 units of device, whereas the control was 74 units of device. Further increases in dosage of pea flour reduce the quality of the gluten. Thus, with increasing of gram flour from 7.5 to $20 \%$ of reading IIR-1 vary from 78 to 98 units of device. Hydration capacity of wheat flour by adding 2.5 ; $5 \%$ of pea flour is similar to the control sample, while the control is $190 \%$. With the increase of pea flour from 7.5 to $20 \%$ the hydration ability increases by $3 \%$ - 35\% compared with the 
control. Thus, with increasing dosages of leguminous flour hydration ability test deteriorates. Similar changes were observed in the elasticity and extensibility as the content of pea flour. From structural and mechanical properties depend on the rheological behavior of gluten pasta.

The results of studies of the effect of pea flour to physical properties of the dough from wheat flour first grade are shown in Table 2.

The data obtained by the alveograph shows that compressive deformation of dough decrease in the increasing process of the maintenance of a pea flour from 2.5 to $20 \%$. Thus, with increasing content of pea flour this figure drops to 0-15,6\% (except for the sample containing $2.5 \%$ pea flour) compared with the control sample.

Table 1. Effect of different doses of pea flour on the properties of gluten flour

\begin{tabular}{|c|c|c|c|c|c|}
\hline $\begin{array}{l}\text { The content of } \\
\text { pea flour, \% }\end{array}$ & $\begin{array}{c}\text { The content of wet } \\
\text { gluten, \% }\end{array}$ & $\begin{array}{l}\text { Extensibility, } \\
\text { sm }\end{array}$ & Flexibility & $\begin{array}{c}\mathrm{N}_{\text {def }}^{\text {IDK }}, \\
\text { device unit }\end{array}$ & $\begin{array}{r}\text { Hydration } \\
\text { ability, \% }\end{array}$ \\
\hline Control & 33,0 & 12,0 & good & 74 & 190 \\
\hline 2,5 & 32,5 & 13,0 & good & 72 & 186 \\
\hline 5 & 31,9 & 12,5 & good & 74 & 189 \\
\hline 7,5 & 31,4 & 11,5 & good & 78 & 193 \\
\hline 10 & 31,0 & 10,5 & satisfactory & 85 & 205 \\
\hline 12,5 & 30,5 & 10,5 & satisfactory & 87 & 211 \\
\hline 15 & 29,7 & 10 & satisfactory & 90 & 215 \\
\hline 17,5 & 29,0 & 10 & satisfactory & 95 & 219 \\
\hline 20 & 28,4 & 9 & unsatisfactory & 98 & 225 \\
\hline
\end{tabular}

Table 2. The effect of pea flour to physical properties of the dough

\begin{tabular}{|c|c|c|c|c|c|c|c|c|}
\hline \multirow[b]{2}{*}{ 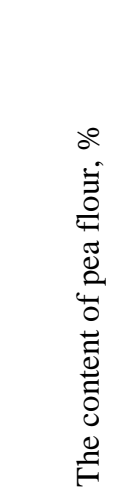 } & \multicolumn{3}{|c|}{ Indicators of alveograph } & \multicolumn{5}{|c|}{ Indicators of farinograph } \\
\hline & 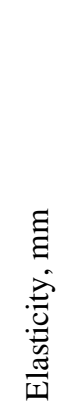 & 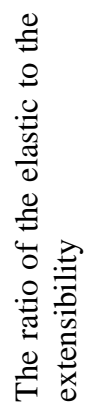 & 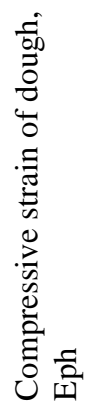 & 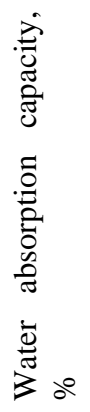 & 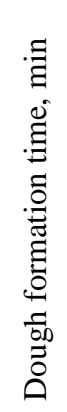 & 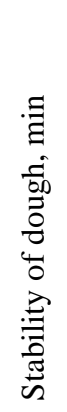 & 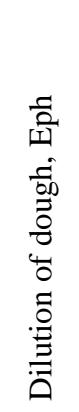 & 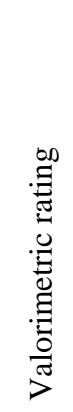 \\
\hline Control & 142 & 2,20 & 326 & 65,0 & 2,0 & 0,5 & 80 & 48,5 \\
\hline 2,5 & 145 & 2,22 & 328 & 65,0 & 2,0 & 0,5 & 75 & 48,5 \\
\hline 5,0 & 143 & 2,21 & 326 & 64,5 & 2,0 & 0,5 & 79 & 48 \\
\hline 7,5 & 140 & 2,19 & 321 & 64,5 & 2,0 & 0,5 & 83 & 47,5 \\
\hline 10,0 & 131 & 2,07 & 311 & 63,0 & 2,5 & 1,0 & 93 & 46,5 \\
\hline 12,5 & 120 & 2,01 & 305 & 63,0 & 2,5 & 1,0 & 98 & 45,5 \\
\hline 15,0 & 108 & 1,93 & 293 & 61,0 & 3,0 & 1,0 & 107 & 43 \\
\hline 17,5 & 101 & 1,85 & 284 & 60,0 & 3,0 & 1,0 & 114 & 42 \\
\hline 20 & 90 & 1,83 & 275 & 60,0 & 3,0 & 1,0 & 123 & 41 \\
\hline
\end{tabular}


The same nature of indicators change of elasticity and the relation of elasticity to tensile properties is observed. So, at the contents to $5 \%$ of a pea flour value of an elasticity indicator of dough is $0,7 \%$ higher in comparison with control, and then there is a dough deterioration in process of increase in the maintenance of a leguminous flour. Elasticity of dough with increase in the maintenance of a pea flour decreases by 1,4-36,6\% in comparison with control. In process of increase in the maintenance of a pea flour from 2,5 to $20 \%$ the relation of elasticity to tensile properties decrease with 2,22 to 1,83 . At initial control 2,20 (Dexter et al, 1983).

The obtained data on a farinograph, allows claiming that the water absorbing assessment of dough, stability and time of formation of dough with increasing in the maintenance of leguminous flour decrease. In process of increase in the maintenance of a pea flour from 2,5 to $20 \%$ water absorbing ability, decreases by $0-7,7 \%$; valorimetric assessment of dough for $0-15,5 \%$. The same nature of change is observed at indicators time of education and stability of dough.

The indicator of fluidifying of dough in process of increase in the maintenance of leguminous flour rises in comparison with a control sample. This indicator is equal in control 80 , with increase in the maintenance of a pea flour increases with 75 to 123, i.e. fluidifying of dough increased with increase in the maintenance of a pea flour at $3,8-53,7 \%$ in comparison with control (an exception samples with the maintenance of $2,5 \%$ and $5 \%$ of a pea flour make)

For researches of influence of a pea flour on quality of pasta used the first grade flour wheat with the maintenance of a crude gluten of 33,0\% of average quality. Pea flour brought in number of 2,$5 ; 5,0 ; 7,5 ; 10,0 ; 12,5 ; 15,0 ; 17,5$ and $20,0 \%$ to the mass of wheat flour. As the control was the sample without additives.

The quality of the cooked pasta were determined before and after cooking, setting the physico-chemical, sensory and cooking properties: duration of cooking until readiness, coefficient of products' increase in mass (KM), coefficient of increase in volume (TO), amount of solids of the welded products which passed into cooking water, safety of a form.

The Influence of a pea flour on quality of ready pasta are presented in table 3 . According to table 3 on organoleptic indicators the best there was pasta with introduction to $7,5 \%$ of a pea flour: they had the correct form, didn't stick together, color of products was monophonic, i.e. didn't

Table 3. The influence of a pea flour to indicators of quality of pasta

\begin{tabular}{|c|c|c|c|c|c|c|c|c|c|}
\hline \multirow[t]{2}{*}{ Indicator } & \multirow[t]{2}{*}{ Contol } & \multicolumn{8}{|c|}{ The content of pea flour, \% } \\
\hline & & 2,5 & 5 & 7,5 & 10 & 12,5 & 15 & 17,5 & 20 \\
\hline Humidity , \% & 13,0 & 13,0 & 13,0 & 13,0 & 13,2 & 13,2 & 13,0 & 13,2 & 13,4 \\
\hline Acidity, hail & 2,8 & 2,8 & 3,0 & 3,2 & 3,6 & 3,6 & 3,8 & 3,8 & 4,0 \\
\hline The ash content, \% on NE & 0,68 & 0,69 & 0,73 & 0,78 & 0,85 & 0,93 & 1,03 & 1,12 & 1,19 \\
\hline The surface condition & $\begin{array}{l}\text { white with } \\
\text { gray shade }\end{array}$ & White & \multicolumn{2}{|c|}{$\begin{array}{l}\text { white with } \\
\text { yellow shade }\end{array}$} & \multicolumn{3}{|c|}{ light - yellow } & \multicolumn{2}{|c|}{ yellow } \\
\hline $\begin{array}{l}\text { The surface condition } \\
\text { Cooking properties: }\end{array}$ & $\begin{array}{c}\text { smooth } \\
7\end{array}$ & 7 & $7^{\text {sn }}$ & oth 7 & 8 & 8 & 9 & 9 & 9 \\
\hline $\begin{array}{l}\text { duration of cooking } \\
\text { until readiness, min }\end{array}$ & & & & & & & & & \\
\hline $\begin{array}{l}\text { Increasing Coefficient of } \\
\text { mass of products }(\mathrm{Km})\end{array}$ & 1,98 & 2,04 & 2,0 & 1,97 & 1,9 & 1,88 & 1,85 & 1,84 & 1,8 \\
\hline $\begin{array}{l}\text { Increasing Coefficient of } \\
\text { volume of products (To) }\end{array}$ & 2,35 & 2,35 & 2,35 & 2,30 & 1,95 & 1,85 & 1,75 & 1,65 & 1,60 \\
\hline $\begin{array}{l}\text { Amount of solids passing } \\
\text { into the cooking water, \% }\end{array}$ & 6,75 & 6,75 & 6,80 & 6,85 & 7,25 & 7,75 & 7,95 & 8,30 & 8,95 \\
\hline $\begin{array}{l}\text { Safety of a form of the } \\
\text { welded products, } \%\end{array}$ & 97 & 98 & 98 & 96 & 90 & 90 & 84 & 80 & 80 \\
\hline
\end{tabular}


observe essential distinctions with a control sample. However, the further increase in dosages of a pea flour was worsened by organoleptic properties of products.

The analysis of the received results showed that introduction of additives promotes deterioration of products. So, in process of increasing in a dosage of a pea flour from 2,5 to $20 \%$ the acidity of products increases from 2.8 to 4.0 degrees, the control in this case is $2.8 \mathrm{deg}$. Ash content increased from 0.69 to $1.19 \%$, in a control sample this indicator made $0,68 \%$.

From table 3 it is shown that in process of increasing in the maintenance of a pea flour from 2,5 to $20 \%$ the cooking duration to readiness increases to 0-2 min. in comparison with control. The coefficient of increasing in mass of products with the increasing in the maintenance of a pea flour decreases in comparison with a control sample by $0,5-9,1 \%$ (an exception is the samples with the maintenance of 2,5 and $5 \%$ of a pea flour). The same pattern of variation of the rate of increasing in the products is observed. The adding of a pea flour in an amount of from 2.5 to $20 \%$ reduces active component to $0-31,9 \%$ compared with the control. In close connection with these indicators is the main indicator of the cooking properties of pasta the amount of solids passing into the cooking water. Protein-containing additives help to increase the solids content in the cooking medium. Thus, with increasing content of the pea flour active component increases to $0-32,6 \%$ compared with the control. By increasing the content of pea flour dimensional stability of welded product varies from 98 to $80 \%$, whereas the control was $97 \%$.

Table 4. The influence of ozonated water to the properties of gluten flour from wheat and pea flour

\begin{tabular}{|c|c|c|c|c|c|}
\hline $\begin{array}{l}\text { The content of pea } \\
\text { flour, \% }\end{array}$ & $\begin{array}{c}\text { Content of a wet } \\
\text { gluten, \% }\end{array}$ & $\begin{array}{c}\text { Extensibilit } \\
\text { y, sm }\end{array}$ & Flexibility & $\begin{array}{c}\mathrm{N}_{\text {def }} \text { IDK } \\
\text { Device unit }\end{array}$ & $\begin{array}{c}\text { Hydration ability, } \\
\%\end{array}$ \\
\hline control & 33,0 & 12,0 & good & 74 & 190 \\
\hline \multicolumn{6}{|c|}{ ozone concentration $1 \mathrm{mg} / \mathrm{l}$} \\
\hline 2,5 & 32,5 & 13,0 & good & 72 & 186 \\
\hline 5 & 31,9 & 12,5 & good & 70 & 188 \\
\hline 7,5 & 31,4 & 12,0 & good & 74 & 189 \\
\hline 10 & 31,0 & 11,5 & good & 80 & 192 \\
\hline 12,5 & 30,5 & 11,5 & good & 84 & 195 \\
\hline 15 & 29,7 & 10,5 & satisfying. & 85 & 201 \\
\hline 17,5 & 29,0 & 10,0 & satisfying. & 89 & 206 \\
\hline 20 & 28,4 & 10,0 & satisfying. & 93 & 212 \\
\hline \multicolumn{6}{|c|}{ ozone concentration 2 mg/l } \\
\hline 2,5 & 32,5 & 13,5 & good & 69 & 184 \\
\hline 5 & 31,9 & 13,5 & good & 70 & 185 \\
\hline 7,5 & 31,4 & 12,5 & good & 70 & 185 \\
\hline 10 & 31,0 & 12,0 & good & 73 & 188 \\
\hline 12,5 & 30,5 & 12,0 & good & 74 & 188 \\
\hline 15,0 & 29,7 & 11,5 & good & 76 & 192 \\
\hline 17,5 & 29,0 & 10,5 & satisfying. & 83 & 197 \\
\hline 20 & 28,4 & 10,0 & satisfying. & 87 & 203 \\
\hline \multicolumn{6}{|c|}{ ozone concentration 3 mg/l } \\
\hline 2,5 & 32,5 & 13,0 & good & 70 & 186 \\
\hline 5 & 31,9 & 13,0 & good & 70 & 189 \\
\hline 7,5 & 31,4 & 12,0 & good & 74 & 190 \\
\hline 10 & 31,0 & 12,0 & good & 78 & 190 \\
\hline 12,5 & 30,5 & 11,5 & good & 80 & 195 \\
\hline 15,0 & 29,7 & 10,5 & satisfying. & 85 & 199 \\
\hline 17,5 & 29,0 & 10,0 & satisfying. & 87 & 205 \\
\hline 20 & 28,4 & 9,5 & satisfying. & 90 & 210 \\
\hline
\end{tabular}


Thus, researches have shown, that the most positive impact to the quality of cooked pasta had pea flour additives in an amount of 7.5\%.

To reduce the deleterious influence of pea flour on the technological properties of pasta was used ozonated water with different ozone concentrations (Table 4). In this regard, firstly we studied the effect of ozonated water on the properties of gluten from wheat flour of the first grade, and legumes.

As it was shown above with increasing in the maintenance of a pea flour from 2,5 to $20 \%$ when using conventional water the maintenance of a crude gluten decreased. When using the ozonized water this regularity remains and the maintenance of gluten remains at the same level,

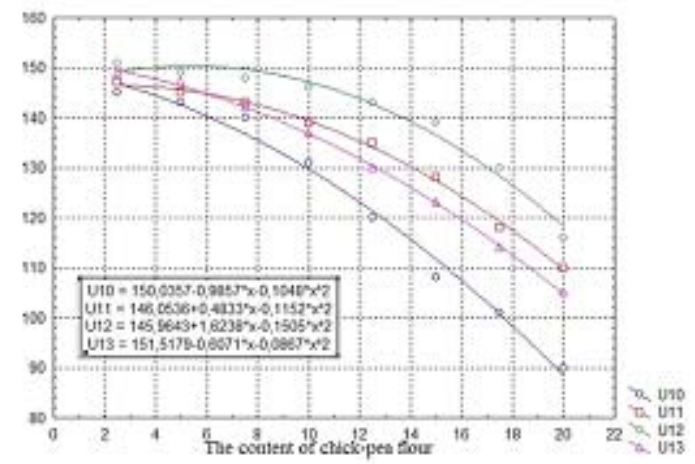

Fig. 1. The influence of ozonated water on the elasticity (a) and dilution of the dough (b) from a mixture of wheat flour and pea

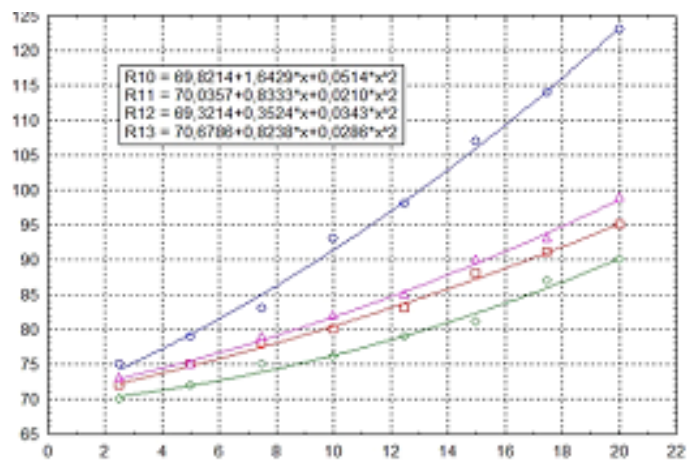

Fig. 3. The comparable graph of ozonated water on the elasticity (a) and dilution of the dough (b) from a mixture of wheat flour and pea as well as without use of the ozonized water. However, there has been a significant increasing in the strength characteristics of gluten, the quality of gluten in the application of ozonated water is improved.

According to the table of 4 instrument readings of IDK with increasing in the maintenance of a pea flour from 2,5 to 20\% changed in use of the ozonized water with concentration of ozone $1 \mathrm{mg} /$ l from 72 to 93 units of the device, at concentration of ozone $2 \mathrm{mg} / \mathrm{l}$ - from 69 to 87 units of the device, at concentration of ozone $3 \mathrm{mg} / \mathrm{l}$ - from 70 to 90 units of the device, and in samples without using the ozonized water the instrument reading changed from 72 to 98 units of the device.

The obtained data on a farinograph

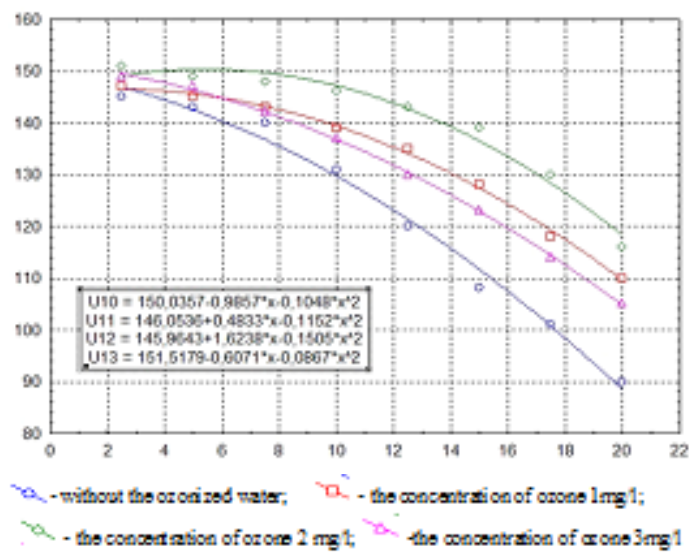

Fig. 2. The influence of the ozonized water on coefficient of increasing in mass of products from mix of a flour wheat and pea

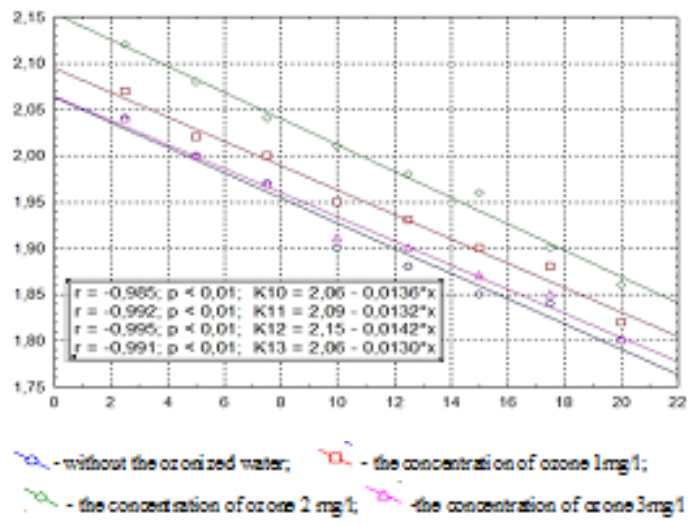

Fig. 4. The influence of the ozonized water on coefficient of decreasing in mass of products from mix of a flour wheat and pea 
shows that dough fluidifying with increasing in the maintenance of a pea flour improves at concentration of ozone $1 \mathrm{mg} / \mathrm{l}$ - to 4,0 - 22,8; $2 \mathrm{mg} /$ $\mathrm{l}$ - to $6,7-26,8$ and $3 \mathrm{mg} / \mathrm{l}-$ to $2,7-19,5 \%$ in comparison with samples without using the ozonized water.

From the received results of influence researches of the ozonized water with concentration of ozone 1, 2, $3 \mathrm{mg} / \mathrm{l}$ on quality of pasta from mix of a first grade flour wheat and pea follows, that use of the ozonized water promotes improvement of quality of products in comparison with samples without using the ozonized water. So, use of the ozonized water allowed to increase coefficient of increasing in mass of products $(\mathrm{Km})$. In process of increasing in the maintenance of a pea flour from 2,5 to $20 \%$ of $\mathrm{Km}$ increases in comparison with samples without using the ozonized water at concentration of ozone $1 \mathrm{mg} / \mathrm{l}$ by $1,47-0,11 \%$, at concentration of ozone $2 \mathrm{mg} /$ - for 3,9-3,3\%, at concentration of ozone $3 \mathrm{mg} / \mathrm{l}$ - for 0-0\% (figure 2).

On organoleptic indicators the cooked pasta with addition of $15 \%$ of a pea flour was the best at use of the ozonized water with concentration of ozone $2 \mathrm{mg} / \mathrm{l}$ : they had the correct form, a smooth surface, didn't stick together, color of products was monophonic, slightly brightened not darkened in the course of cooking, a consistence of products are elastic, cooking liquid slightly muddy. Thus, the ozonated water with the ozone concentration 2 $\mathrm{mg} / \mathrm{l}$ and addition of $15 \%$ pea flour influenced largest positive effect on the quality of the cooked pasta.

\section{DISCUSSION}

The analysis of the obtained data showed that using the ozonized water improves the hydration ability of a gluten in comparison with samples without using the ozonized water. So, with increasing in dosages of a pea flour, the hydration ability improves to $0-13,0 \%$ at use of the ozonized water with concentration of ozone $1 \mathrm{mg} / \mathrm{l}$, to $2-22 \%$ - at concentration of ozone $2 \mathrm{mg} / \mathrm{l}$, to $0-15 \%$ - at concentration of ozone $3 \mathrm{mg} / \mathrm{l}$ in comparison with samples without using the ozonized water (Matsuo \& Dexter, 1980). Similar changes are observed at tensile properties and elasticity indicators (Feillet, 1984).

Thus, the received results of researches testify about positive influence of the ozonized water on quality of a gluten, on its hydration ability, and also on tensile properties and elasticity (Faridi, 1987). Using the ozonized water with concentration of ozone at $2 \mathrm{mg} / \mathrm{l}$ allowed to increase a dosage of a pea flour to $15 \%$ to the mass of wheat flour of the first grade, thus the indicators characterizing properties of a gluten didn't concede to a control sample (Dzhiki \& Laskowski, 2001).

For studying the influence of the ozonized water on rheological properties of dough from mix of a flour wheat and leguminous estimated changes of physical properties of dough on Chopin's alveograph and Brabender's farinograph (Dzhiki \& Laskowski, 2001).

The obtained data show, that at use of the ozonized water the elasticity of dough in process of increasing in the maintenance of a pea flour from 2,5 decreases to $20 \%$, but its value above, than in samples without the ozonized water (figure 1). In process of increasing in the maintenance of a pea flour the elasticity of dough increases in comparison with samples without use of the ozonized water at use of the ozonized water with concentration of ozone $1 \mathrm{mg} / \mathrm{l}$ - to $1,4-22,2 \%$, at concentration of ozone $2 \mathrm{mg} / \mathrm{l}$ - to $4,1-28,9 \%$, at concentration of ozone $3 \mathrm{mg} / \mathrm{l}$ - to 2,6-16,6\% (Dzhiki \& Laskowski, 2003).

\section{CONCLUSION}

Based on the results of studies of the effect of flour from leguminous cultures on the quality of gluten, dough properties and quality of the cooked pasta is the optimal dosage pea flour $7.5 \%$ by weight of wheat flour of the first grade, a further increase in dosage legumes flour leads to deterioration of the technological properties of pasta.

Found that the use of ozonated water in the preparation of the test helps to improve the technological properties of pasta from a mixture of wheat flour and grain legumes; determined that in terms of improving the quality of pasta optimal dosage pea flour is $15 \%$, the ozone concentration of $2 \mathrm{mg} / \mathrm{l}$. The use of flour from leguminous cultures suitable for enrichment of pasta valuable food components are proteins, essential amino acids, vitamins and minerals. 


\section{REFERENCES}

1. Abdraimov N. National Healthcare Development Program of the Republic of Kazakhstan "Salamatty Kazakhstan" for 2011 - 2015. DOI: 10.1021/jf60222a045

2. Medvedev G.M. Technology of pasta. Petersburg, 2005-312p. DOI: 10.1111/ jfpe. 12173

3. Iskakova G.K., Iztaev A.I., Kulazhanov T.K., Maemerov M.M., Iztaev B.A. Technology of bread and pasta with ozonated water and ionozonated water (monograph).-Almaty: TUA, 2011.-216 p. doi: 10.3109/ 09637486.2013 .766152

4. Kulazhanov K.S., Iskakova G.K., Iztaev A.I. Improving the technology of bread flour-based leguminous cultures and ozonated water (monograph).- Almaty: TUA, 2008 - 176 p. DOI:10.1080/10408390903001693

5. Kosovan A.P., Polandova R.D. New conceptual solutions baking and noodle industry // Storage and processing of agricultural raw materials. 2004. - 16. - P.49-51, DOI: 10.4236/ fns.2012.34062

6. Panzhin D. Pasta production in Russia: raw materials and technological trends // Bakery. 2006. - N11. - P.28-29. DOI: 10.4236/ fns.2012.31005

7. Maemerov M.M., Iztaev A.I., Kulazhanov T.K., Iskakov G.K. Scientific bases of ionoozonated processing technology of grain and products of its processing (monograph). - Almaty: Aleiron, 2011.-246 p. doi:10.1080/ 003655200750023002

8. Laboratory workshop on the common technology of food production / Ed. LP Kovalskoy.- M .: Agropromizdat, 2001-336sp. doi:10.1079/BJN20041350

9. Vasilenko I.I, V.I Komarov, Assessment of the quality of grain. TH .: Agropromizdat, 2007.208p. doi:10.1016/S0144-8617(02)00268-0

10. Abecassis J., Durum wheat milling: principles and effects on pasta quality. Cereal Foods World, 2001 46, 357-358. doi:10.1016/S0260-
8774(03)00169-9

11. Cacak-Pietrzak G., Haber T., Lewczuk J., Madrias M., Quality evaluation of selected extra pasta on the Warsaw market. Przeg. Zbo $\dot{c}-\mathrm{M}^{3} \mathrm{yn}$. 2007, 41, 26-29 (in Polish). doi:10.1016/ j.jfoodeng.2006.12.016

12. D’Egidio M.G., Mariani B.M., Nardi S., Novaro P., Cubadda, R., Chemical and technological variables and their relationships: A predictive equation for pasta cooking quality. Cereal Chem., 2010, 67, 275-281.

13. Del Nobile M.A., Massera M., Modeling of water sorption kinetics in spaghetti during cooking. Cereal Chem.,2000, 77, 615-619. doi:10.1016/S0377-0257(98)00189-X

14. Dexter J.E., Matsuo R.R., Morgan B.C., Spaghetti stickiness: Some factors influencing stickiness and relationship to other cooking quality characteristics. J. Food.Sci., 2003, 48, 1545-1551. doi:10.1201/9781439832271

15. Dziki D., Laskowski J., Investigations into the effect of cooking time of pasta on changes in extraction parameters. Acta Agrophysica, 2001, 46, 47-53 (in Polish).

16. Dziki D., Laskowski J., Ziegler A., Effect of selected factors on culinary traits of pasta. - ywnoœæ. Nauka. Technologia. Jakoœæ, 2003, 35, 125-134 (in Polish). doi:10.1016/ j.foodres.2009.07.020

17. Faridi H., Rheology of Wheat Products. 1987, AACC, St. Paul. p. 231. doi:10.1016/ j.jfoodeng.2007.03.037

18. Feillet P., The biochemical basis of pasta cooking quality. Sci. Aliments, 1984, 4, 551-568. d o i : 10 . $1002 /$ ( S I C I ) 1097 4628(19990919)73:12<2429::AID APP11>3.0.CO;2-B

19. Feillet P., Autran J.C., Icard-Vernière Ch., Pasta brownness: an assessment. J. Cereal Sci., 2000, 32, 215-233. doi:10.1016/j.jcs.2008.09.007

20. Matsuo R.R., Dexter J.E., Comparison of experimentally milled durum wheat semolina to semolina produced by some Canadian commercial mills. Cereal Chem., 2010, 57, 117122. doi:10.1021/jf0106953. 